Frank Smart Studentship as the best student of his year and remained at Cambridge to take a PhD, awarded in 1936. He was awarded an ScD in 1951. His professional career started at Long Ashton Research Station in 1934 and he joined ICI in 1936, where he remained until 1963 first at Jealott's Hill and later at the Akers Laboratories. He returned to academic life in 1963 as Regius Professor of Botany in Glasgow; in 1968 he moved to Cambridge as Professor of Botany, where he stayed until his retirement in 1977 . He was awarded an honorary DSc by Hull University in 1978.

Brian's most productive years as a research worker were spent at the Akers Laboratories. Here he collected an active research group and enjoyed close collaboration with organic chemists who shared his interest in natural products. His research planning and management were faultless; he maintained his interest in a problem only as long as the results justified the work involved; he noticed potential developments peripheral to his central theme, but he did not pursue them until he could give them adequate backing; he did not fritter his energy on red herrings. Once he had launched a new line of research, he gave the workers themselves complete freedom to develop it. The result was a happy, well-integrated and purposeful group.

Brian's central interest as the Akers Laboratories was the influence of antibiotics on the balance of fungi in the soil; this involved collecting antibiotics from soil fungi, examining their effects on other fungi and on higher plants and trying to establish whether the same chemicals were produced in soils. Brian was not deterred by the magnitude and complexity of this problem. During the course of this work he noticed that although most of the antibiotics were generally toxic, a few, notably griseofulvin, were more specifically active against fungi and might have a potential in plant chemotherapy. Brian launched a programme to study this possibility some 10 years before the subject became respectable. Griseofulvin was never sucessful as a plant chemotherapeutant, but found a unique place in the treatment of mycoses in man and other animals, a possibility which Brian foresaw some years before the chemical was developed.

The chemical interactions of soil fungi included the activity of parasites as well as saprophytes. Among other parasites he studied the products of Gibberella fujikuori and isolated the active chemical, gibberellic acid, in large enough quantities to launch a new area of botanical research. The interactions between fungal parasites and their hosts, particularly as related to the balance of hormones in the plant, remained Brian's central research interest. He pursued these studies at Glasgow and Cambridge with the support of the Agricultural Research Council. The ARC Unit of Developmental Botany was established at Cambridge in
1969 with Brian as honorary director. Here hormone physiology was studied in both healthy and diseased plants.

Brian had less time for research in his university posts but he was known as a tower of strength in his departments and he and his wife, Meg, were untiring in their hospitality to students and to their colleagues.

In addition to research and teaching, Brian was unstinting in the time he would give to the substructure of his science. He was a member of the Agricultural Research Council, twice president of the British Mycological Society, president of the Association of Applied Biologists, the Society of General Microbiology and of the Cambridge Philosophical Society at the time of his death. He was vice-president of the Institute of Biology and served on the council of the Society for Experimental Biology. He also maintained his interest in plant pathology and was one of the chief organisers of the 1st International Congress of Plant Pathology. He was elected a Fellow of the Royal Society in 1958 and served on its Council from 1968 to 1970. He delivered the Leeuwenhoek Lecture in 1966. He was created CBE in 1975.

Brian was never a loquacious man and never pushed himself forward. However, he never refused help and advice when it was requested or needed and what he did say was to the point and well worth listening to. It was probably a measure of his greatness that so many people 'beat a path to his door.' He will be sorely missed by his friends and colleagues and particularly by his family, who must command our deepest sympathy.

S.H. Crowdy

\section{Martin Prestige}

Martin Calder Prestige, developmental biologist and Senior Lecturer in Physiology at Edinburgh University, died suddenly on 27 August 1979.

His death, at the early age of 44 , removes from the world of developmental neurobiology one of its most incisive minds and able investigators. Educated at Cheltenham College and Trinity College, Cambridge, his basic scientific training was in physiology and led to his being awarded a Michael Foster Studentship. In 1958 he started research, with Patrick Merton, on the occurrence of initial collaterals on kitten motorneurons.

In 1963 Martin joined Arthur Hughes in work on the development of the amphibian spinal cord. This collaboration started in the Anatomy School in Cambridge, continued from 1964 at the Zoology
Department in Bristol, and had a great and continuing effect on the general direction of his work. He took his PhD at Bristol in 1967; this was on the development of the nervous system to he hind leg of Xenopus tadpoles and it outlined what was to be one of his main research interests. He continued working in Bristol until he moved to Edinburgh as a Lecturer in Physiology in 1968. He loved Edinburgh and remained there, being appointed Senior Lecturer in 1975.

Two main themes run through Martin's work. The first concerns how the nervous system is put together in terms of cell types and cell numbers; and, with a slight modification of emphasis, this changes into the second theme, which concerns how the system is established in terms of adult functional connectivity.

In Martin's early work his friendship with Arthur Hughes shows most clearly, for he started from Hughes' observations on development in Xenopus and extended these brilliantly. In a series of papers starting in 1965 he analysed the phenomena of cell death during the development of the spinal cord and its sensory and motor connections. This was beautiful work, highly relevant to ideas that were then beginning to emerge on the role of centralperipheral relationships in the developing nervous system, and it continued up to his death, with a paper currently submitted for publication.

In 1975 the second main theme of Martin's work was illustrated by the publication, with David Willshaw, of their now well-known paper on theoretical aspects of the formation of retinotectal connections. This paper was very important in that it introduced, for the first time, a welcome touch of rigour into the study of how the eye connects with the brain. Up till then there had been, unbelievably, virtually no serious assesssment of the assumptions underlying the various mechanisms that had been proposed to account for the formation of retinotectal connections. Since then there have been several (and more comprehensive) papers on this subject, by others, but the initial credit must go to Prestige and Willshaw.

Martin was also a poet of considerable ability. He had, in his youth, been a mountaineer, and he maintained this interest until his death, in the form of an extensive collection of books on the Himalayas. His first wife, Anne, was killed in a tragic accident. He was married for a second time, to Lucina, in 1972, and their further years in Edinburgh were happy.

In the last year of his life Martin was much troubled by respiratory disability resulting from an illness in youth. Those who knew him over the years will miss him as a friend, as a distinguished scientist, as an inspiration to his colleagues and as an outstanding example of how to behave in the face of adversity.

R.M. Gaze. 